Jacek Grzywacz*

Ewa Jagodzińska-Komar**

\title{
ROLA BANKÓW I SEKTORA FINTECH W ŚWIETLE IMPLEMENTACJI DYREKTYWY PSD2
}

\section{Wprowadzenie}

Pojawiające się na rynku usług płatniczych nowe rodzaje płatności oraz zwiększona liczba płatności elektronicznych wymusiły na Unii Europejskiej opracowanie nowych regulacji prawnych, które uporządkują rynek płatności detalicznych. Przewiduje się, że nowa dyrektywa PSD2 zmusi banki do współpracy z sektorem finansowym i sektorem FinTech. Polski sektor bankowy jest nowoczesny w porównaniu z sektorami bankowymi innych państw Unii Europejskiej dzięki zaawansowanym systemom IT i właśnie dlatego w Polsce wdrażane są innowacje płatnicze. Mimo to polskim bankom nie udało się do tej pory wejść na rynki zagraniczne w zakresie dostępu do API. Polski sektor bankowy nadal nie wykorzystuje szans, jakie niesie wdrożenie interfejsu API. Warto zwrócić uwagę, że sektor FinTech nie chce podbijać rynku, lecz stara się nawiązać współpracę z bankami. Nowe regulacje prawne wpłyną na rozwój sektora FinTech.

Dyrektywa PSD2 będzie wymagała od sektora bankowego zmian na wielu płaszczyznach, a mianowicie: prawnej, technologicznej oraz strategicznej. Wydatki będą skierowane przede wszystkim na obszar compliance ${ }^{1}$. Według sektora bankowego w Europie Środkowej zmiany zaczną być zauważalne w przeciągu dwóch lub trzech lat od implementacji tej dyrektywy. Sytuacja przedstawia się inaczej w Europie Zachodniej, gdzie pierwsze efekty są oczekiwane już po pierwszym roku, ze względu na bardziej rozwinięty sektor FinTech.

Banki obawiają się, że stracą swoją dominującą rolę ze względu na pojawienie się nowych podmiotów na rynku usług płatniczych, czyli nowej kategorii instytucji płatniczych, tzw. third party providers (TTP). W tej kategorii można rozróżnić dwa

* Kolegium Nauk o Przedsiębiorstwie, Szkoła Główna Handlowa w Warszawie.

* PKO Bank Polski SA.

1 Compliance jest to zgodność funkcjonowania zgodnie z regulacjami prawnymi. 
rodzaje instytucji płatniczych: pierwsza to instytucje, które będą inicjować płatność oraz świadczyć ten rodzaj usługi w internecie, natomiast druga to podmioty, które będą zapewniać konsumentom całościowe informacje na temat ich rachunków bankowych (za pomocą jednej aplikacji klient sprawdzi w szybki sposób swoją sytuację finansową). Podmioty trzecie będą mogły przeprowadzać operacje finansowe po uzyskaniu zgody klienta.

Głównym celem artykułu jest analiza roli sektora bankowego oraz FinTech w kontekście implementacji dyrektywy PSD2 oraz określenie perspektyw współpracy między bankami a sektorem FinTech.

$\mathrm{W}$ artykule zostały zaprezentowane wnioski dotyczące europejskiego rynku płatności, który stoi przed dużym wyzwaniem związanym z wdrożeniem tej unijnej dyrektywy. $Z$ drugiej strony to rozwiązanie prawne może spowodować, że Unia Europejska będzie miała szansę stać się najbardziej innowacyjnym rynkiem usług płatniczych na arenie międzynarodowej.

\section{Rola banków w kontekście dyrektywy PSD2}

Duże banki działające na terenie Europy Środkowej podjęły działania związane z implementacją dyrektywy o usługach płatniczych PSD2 ${ }^{2}$, natomiast małe banki czekają na rozwój wydarzeń i wtedy zdecydują co do swego stosunku do unijnej dyrektywy. Według badania przeprowadzonego przez Deloitte 30\% banków w Polsce uważa, że dyrektywa PSD2 jest dla nich szansą, 14\% postrzega ją jako zagrożenie dla funkcjonowania swojej działalności, natomiast około $43 \%$ traktuje dyrektywę PSD2 neutralnie. Według wspomnianego badania banki w Europie Środkowej dzielą się na dwie grupy (banki, które chętnie podejmą wyzwania oraz banki z odwrotnym podejściem, czyli minimaliści). Banki z pierwszym podejściem starają się maksymalnie wykorzystać rysujące się przed nimi możliwości, zarówno pod względem dostosowania do unijnych przepisów, jak również do zmiany swojej strategii biznesowej (okazja do nawiązania współpracy z sektorem FinTech). Druga grupa skupia się jedynie na dostosowaniu do wymagań regulacyjnych ${ }^{3}$.

\footnotetext{
2 Dyrektywa Parlamentu Europejskiego i Rady (UE) 2015/2366 z dnia 25 listopada 2015 r. w sprawie usług płatniczych w ramach rynku wewnętrznego zmieniająca dyrektywy 2002/65/WE, 2009/110/ WE, 2013/36/UE i rozporządzenie (UE) nr 1093/2010 oraz uchylająca dyrektywę 2007/64/WE, DzU UE L.2007.319.1 ze zm.

3 Duże banki w Europie Środkowej przygotowuja się do wejścia w życie PSD2, małe czekaja na rozwój wydarzeń, https://www2.deloitte.com/pl/pl/pages/press-releases/articles/duze-banki-w-europie-srodkowej-przy- gotowuja-sie-do-PSD2.html [dostęp 1.02.2018].
} 
PSD2 to Dyrektywa Parlamentu Europejskiego i Rady (UE) 2015/2366 z dnia 25 listopada 2015 r. w sprawie usług płatniczych w ramach rynku wewnętrznego, która wpłynie na kształt i funkcjonowanie rynku usług płatniczych. Najważniejszym celem unijnej dyrektywy jest zwiększenie ram prawnych dotyczących świadczenia usług płatniczych oraz uzupełnienie dotychczasowych regulacji.

Warto zwrócić uwagę, że od czasu uchwalenia dyrektywy PSD nastąpiły duże zmiany na rynku usług płatniczych pod względem wprowadzanych innowacji płatniczych, które wpłynęły na duży wzrost płatności elektronicznych oraz płatności mobilnych. Dyrektywa PSD2 w całości zastąpi dotychczasowo stosowaną dyrektywę PSD, a jej wdrożenie wprowadzi zmiany w ustawie o usługach płatniczych.

\section{Rysunek 1. Dyrektywa PSD2, harmonogram wdrożenia}

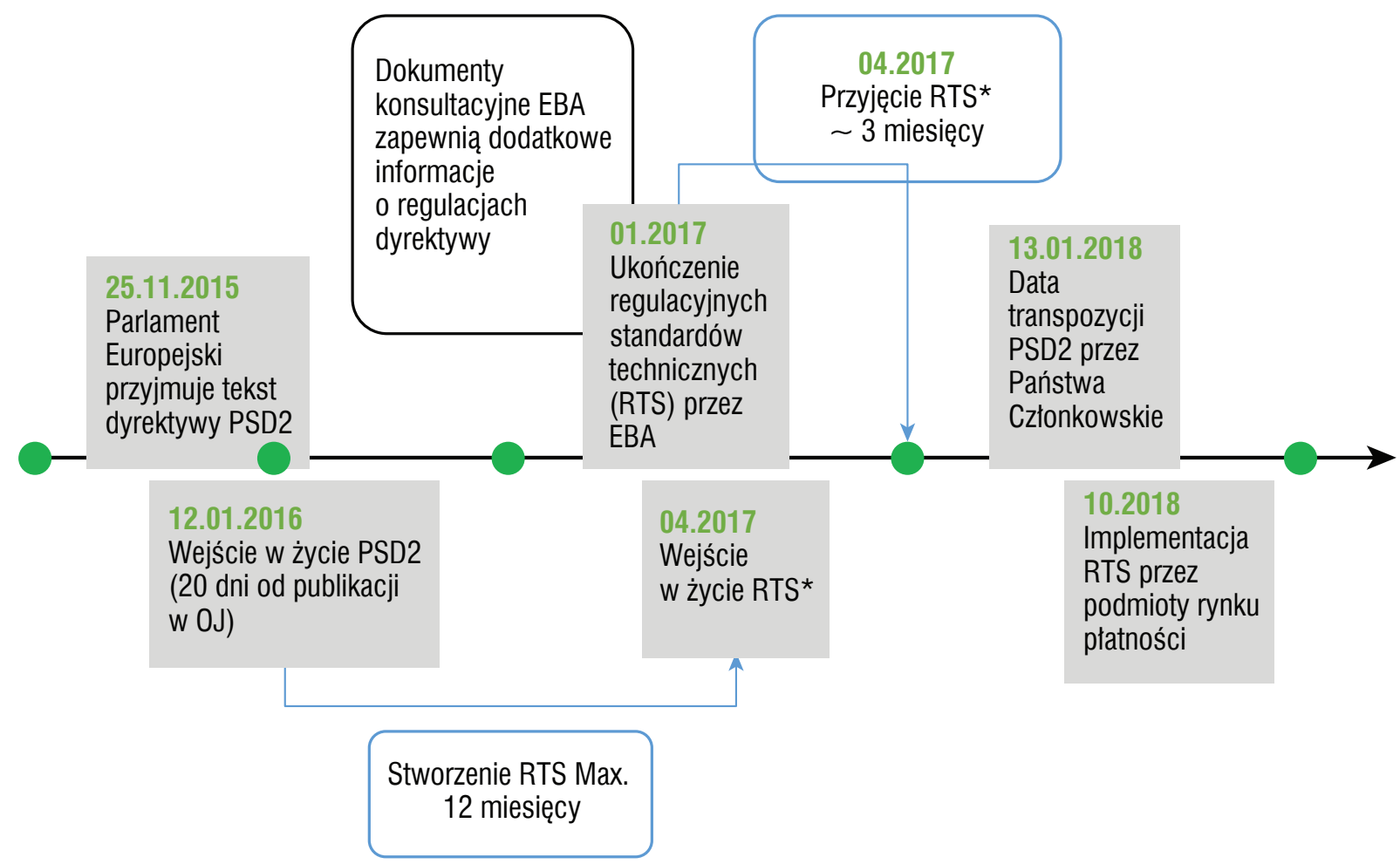

* Termin przyjęcia RTS to najczęściej 3-5 miesięcy od ich opracowania przez EBA. RTS wchodzą w życie 20 dni od publikacji w OJ.

Źródło: Opracowanie własne na podstawie: Wszystko o PSD2 (Payment Services Directive 2), https://www2. deloitte.com/pl/pl/pages/doradztwo-prawne/topics/PSD2.html [dostęp 8.02.2018].

Banki staną przed wyborem strategii po implementacji dyrektywy PSD2. Można rozróżnić dwa warianty strategii, a mianowicie ${ }^{4}$.

4 Dyrektywa PSD2 zmienia rynek. To poczatek ekonomii API, https://www.itmagination.com/pl/booster/ the-psd2-directive-is-changing-the-market/ [dostęp 2.02.2018]. 
1) pierwszy polega na otwarciu się na otoczenie - bank będzie miał możliwość oferowania wszystkich usług finansowych w jednym miejscu, i to bez względu na to, do jakiego banku będzie należał dany produkt;

2) drugi polega na ograniczeniu się do wymagań zawartych w dyrektywie PSD2 - przy takim podejściu dyrektywa będzie stanowić dla sektora bankowego nowe źródło kosztów, a nie przychodów; warto zwrócić uwagę, że przy tej strategii pozycja banków może być zagrożona, ponieważ w tym przypadku rola banków ograniczy się do dostawcy infrastruktury finansowej.

Według słów Daniela Majewskiego, menedżera w zespole Doradztwa Strategicznego dla sektora finansowego w Europie Środkowej, „Banki podejmujące wyzwanie są zmotywowane do działania, ponieważ dostrzegają zagrożenia, które dla ich działalności niesie niewykorzystanie potencjału PSD2. Z drugiej strony, choć minimaliści uznają dyrektywę za szansę, to niewielki odsetek z nich podejmuje jakiekolwiek proaktywne działania, uznając, że sam rynek stworzy im korzystne warunki”"

\section{Nowe rozwiązania wprowadzone przez dyrektywę PSD2}

Dyrektywa PSD2 wprowadza nowe standardy techniczne (RTS) ${ }^{6}$, czyli określenie regulacyjnych standardów technicznych pomiędzy bankami a podmiotami trzecimi (dostawcami usług płatniczych). To rozwiązanie prawne zostało opracowane przez Komisję Europejską oraz Europejski Urząd Nadzoru Bankowego.Według słów Piotra Gałązki, przedstawiciela banków polskich w Brukseli, „Zasada ogólna opublikowanych standardów mówi, że musi być zapewniony dostęp dla podmiotów trzecich, albo przez API (dedykowany dostęp), a jeśli go nie ma - to poprzez interfejs, z którego korzysta konsument, logując się do e-bankowości. Jeśli API nie działa, to TPP może logować się przez interfejs konsumencki. Możliwość tę można wyłączyć, jeśli bank używa sprawdzonego zatwierdzonego przez nadzór API"7.

Nowe zasady mają za zadanie wprowadzić wyższy poziom bezpieczeństwa podczas przeprowadzania transakcji oraz mają umożliwić powstawanie innowacji

\section{Ibidem.}

6 Commission Delegated Regulation supplementing Directive 2015/2366 of the European Parliament and of the Council with regard to regulatory technical standards for strong customer authentication and common and secure open standards of communication, European Commission, Brussels 27.11.2017.

7 Komisja Europejska opublikowała dzisiaj standardy techniczne (RTS) do dyrektywy PSD II, https://alebank.pl/komisja-europejska-opublikowala-dzisiaj-standardy-techniczne=-rts-do-dyrektywy-psd-ii/?id236100\&catid=18911 [dostęp 2.02.18]. 
płatniczych. Z drugiej strony dyrektywa może spowodować spadek liczby transakcji internetowych ze względu na wprowadzenie zabezpieczeń tego typu transakcji.

Implementacja tego unijnego rozwiązania wymusi na bankach współpracę z nowymi podmiotami, czyli third party providers (TPP), które można podzielić na dwie kategorie ${ }^{8}$ :

1) account information services providers - zbieranie danych znajdujących się na różnych kontach bankowych dotyczących klienta w jednym miejscu (łatwiejsze zarządzanie budżetem), np. historia transakcji czy informacja o saldzie;

2) payment initiation service providers - inicjowanie przeprowadzania przelewów bankowych, dzięki czemu płatności internetowe będą dokonywane w łatwiejszy sposób.

Można wyróżnić różnego rodzaje modele TPP, które mogą być skonstruowane jako np. ${ }^{9}$ :

- pełny dostęp do danych na rachunku klienta,

- ograniczony dostęp do danych klienta,

- przekierowanie na stronę banku, w tym przypadku bank udziela gwarancji płatności lub w przypadku braku środków odmawia przeprowadzenia transakcji.

Prognozuje się, że sektor bankowy będzie miał coraz większy udział w rynku szybkich przelewów przeprowadzanych w internecie. Wielu ekonomistów prognozuje, że europejski rynek usług finansowych w przyszłości będzie podobny do rynku energetycznego (wybrane podmioty odpowiedzialne są za produkcje energii, inne jednostki ją dystrybuują, a na koniec jeszcze inne ją sprzedają). Nowa kategoria instytucji płatniczych będzie korzystać z infrastruktury, która została stworzona przez inne firmy.

\section{Przyszłość współpracy sektora FinTech z bankami}

Sektor bankowy w Polsce nie polega na FinTechach w sprawie innowacyjnych rozwiązań, lecz ma nadzieję, że współpraca z tym sektorem poprawi ich efektywność operacyjną przy wykorzystaniu narzędzi analitycznych, np. obliczanie ryzyka kredytowego. Warto zwrócić uwagę, że banki w naszym kraju przewidują w związku

\footnotetext{
8 Dyrektywa PSD2 zmienia rynek..., op.cit.

9 W. Szpringer, M. Szpringer, Nowe zjawiska w regulacji rynku usług płatniczych (wybrane problemy na tle projektu noweli do dyrektywy PSD), „E-mentor” nr 4(56), 2014, s. 73-83.
} 
z powyższym niższe stopy zwrotu $\mathrm{z}$ inwestycji wynikających $\mathrm{z}$ wprowadzenia rozwiązań i produktów sektora FinTech (Polska - 13\%, świat - 20\%) ${ }^{10}$.

Według słów Moniki Kanii, prezes Xchanger, „Współpracy pomiędzy bankami i fintech-ami nie powinniśmy postrzegać w kontekście konkurencji, ale jako możliwość szybkiego rozwoju nowych produktów bez potrzeby dużych nakładów inwestycyjnych. Przekłada się to również na budowanie nowych kanałów dystrybucji, możliwość dotarcia do nowych grup klientów, bądź zbudowania dodatkowej wartości dla już obsługiwanych grup. Duża zmienność oczekiwań klientów i dynamika rozwoju rynku w kierunku zapotrzebowania na nową jakość usług cyfrowych niejako wymusza na spółkach technologicznych i bankach pracę w warunkach interakcji i zmienia sposób, w jaki banki podchodzą do budowania relacji z klientem i procesu utrzymania go w ramach ekosystemu usług. Przykłady takiego podejścia widzimy już m.in. na rynkach niemieckim, brytyjskim, austriackim w postaci mobilnych, modułowych banków budowanych często jako produkty whitelabel w oparciu o usługi dostawców zewnętrznych, czyli właśnie firm fintech"11.

Rysunek 2. Najważniejsze cele sektora finansowego (w \%)

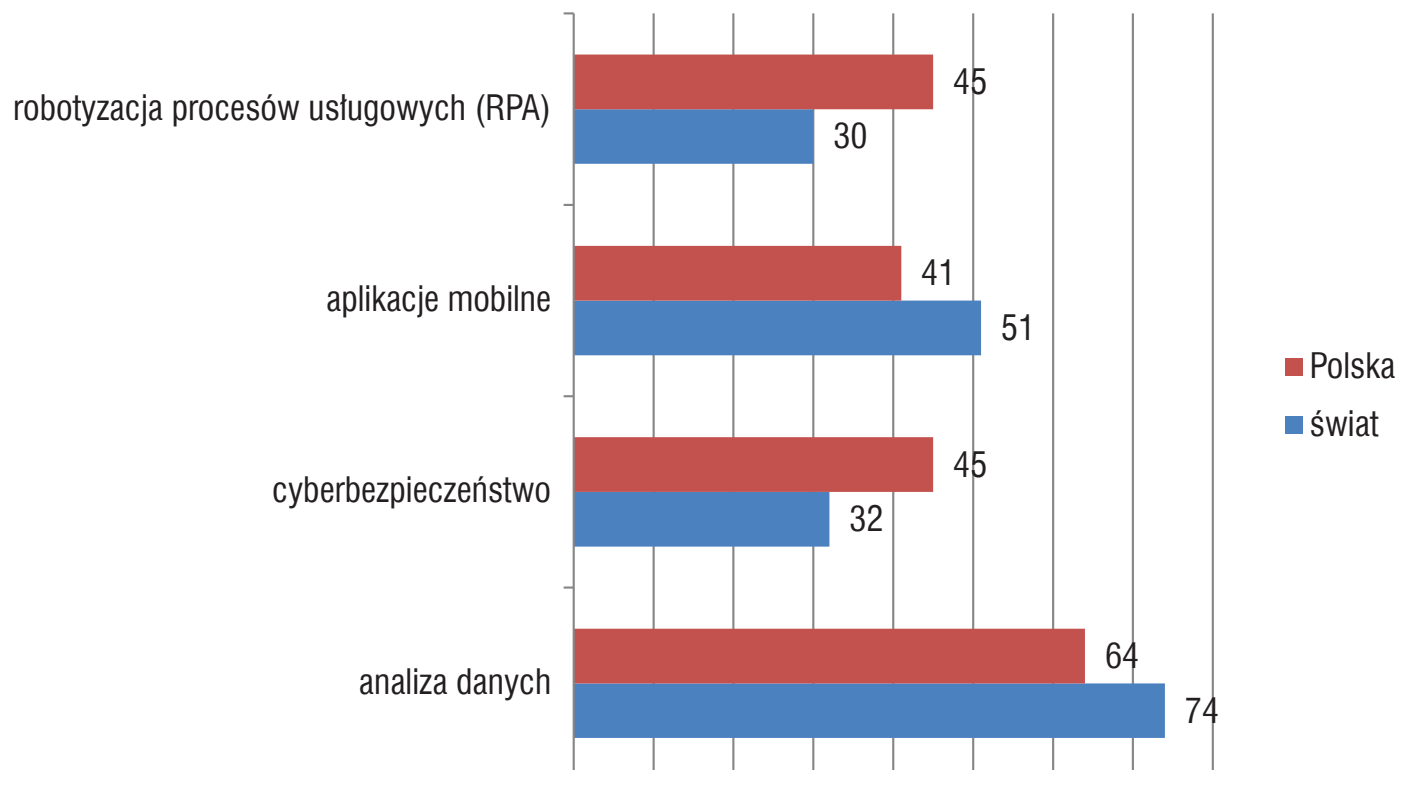

Źródło: Opracowanie własne na podstawie: Banki i fintech-y - małżeństwo z rozsadku, raport PwC, czerwiec 2017, s. 7, https://www.pwc.pl/pl/pdf/fintech-2017-raport-pwc.pdf [dostęp 1.02.2018].

10 Banki i fintech-y - małżeństwo z rozsadku, raport PwC, czerwiec 2017, s. 6, https://www.pwc.pl/pl/ pdf/fintech-2017-raport-pwc.pdf [dostęp1.02.2018].

11 Ibidem, s. 4. 
Według badań ankietowych ${ }^{12}$ przeprowadzonych przez $\mathrm{PwC}$ priorytety sektora finansowego to przede wszystkim wykorzystanie data analytics, aplikacje mobilne, cyberbezpieczeństwo oraz zwiększona efektywność operacyjna (robotyzacja procesów usługowych), co ilustruje rysunek 2. Banki w Polsce nie potrafią jeszcze wprowadzać swoich technologicznych rozwiązań na rynek międzynarodowy.

Sektor FinTech wpłynie na migrację konsumentów do kanałów mobilnych. Ekonomiści przewidują, że za 5 lat właśnie kanał mobilny będzie najważniejszym kanałem komunikacji, a liczba oddziałów samoobsługowych wzrośnie w gwałtownym tempie. Rysunek 3 obrazuje sytuację obecną i zmiany, jakie mają nastąpić w przeciągu 5 lat. Warto zwrócić uwagę, że obecnie banki koncentrują się przede wszystkim na potrzebach konsumentów i w związku z tym w najbliższej przyszłości największy wzrost odnotują strony internetowe i aplikacje mobilne (najbardziej preferowane przez klientów). Media społecznościowe znajdują się na trzeciej pozycji, jednak pomimo postępującej technologii w sektorze bankowym oddziały stacjonarne nie znikną, tylko zmieni się ich rola.

Rysunek 3. Struktura komunikacji z konsumentem (w \%)

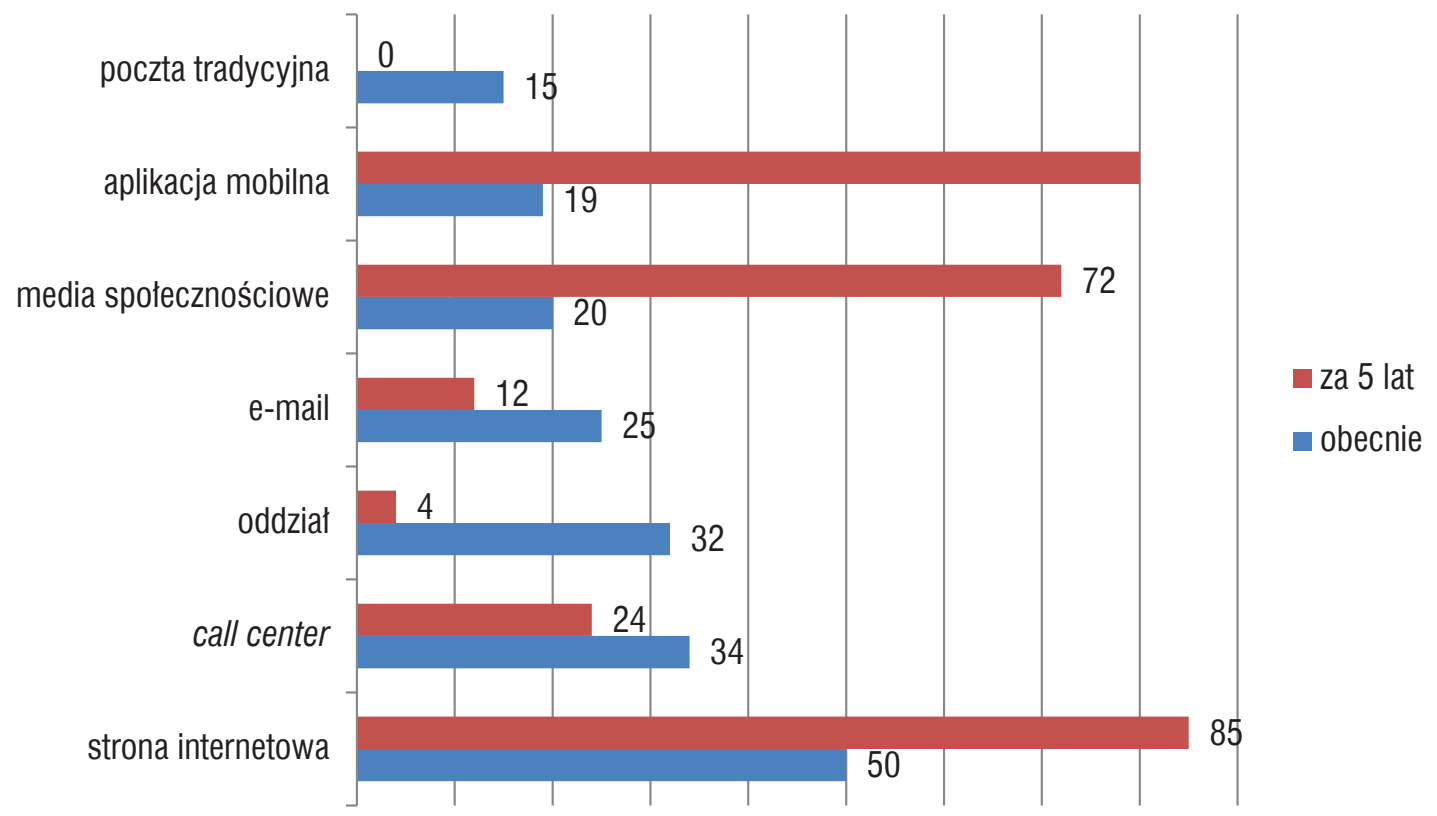

Źródło: Jak do rys. 2, s. 11.

12 Wykorzystano dane z badania PwC Fintech Survey 2017, w badaniu wzięło udział 1308 ankietowanych z 71 państw, Redrawing the lines: FinTech's growing influence on Financial Services, Global FinTech Report 2017, https://www.pwc.com/jg/en/publications/pwc-global-fintech-report-17.3.17-final.pdf [dostęp 5.02.2018]. 
Warto zwrócić uwagę, że na polskim rynku często testowane są międzynarodowe rozwiązania technologiczne, np. karty zbliżeniowe, Android Pay czy aplikacje digitalowe. Banki często szukają współpracy z innymi podmiotami pod konkretny problem w formule white label ${ }^{13}$. Banki w Polsce deklarują, że przeznaczą $4 \%$ swoich przychodów na inwestycje w sektor FinTech (dla porównania poziom globalny wynosi 15\%). Dzięki dyrektywie PSD2 banki otworzą się na współpracę z FinTechami, które liczą, że dzięki tej nowej unijnej regulacji będą kształtować swoje modele biznesowe ${ }^{14}$.

Sektor bankowy powinien postrzegać współpracę z sektorem FinTech jako jeden z czynników do własnego rozwoju (wspólne opracowywanie innowacyjnych rozwiązań płatniczych). Rysunek 4 ilustruje problemy, z jakimi muszą zmierzyć się sektor FinTech oraz bankowy, podejmując współpracę. Banki najczęściej widzą zagrożenie w bezpieczeństwie IT, kolejnym wyzwaniem są regulacje prawne oraz różnice dotyczące zarządzania i kultury organizacyjnej.

\section{Rysunek 4. Wyzwania dla sektorów bankowego i FinTech (w \%)}

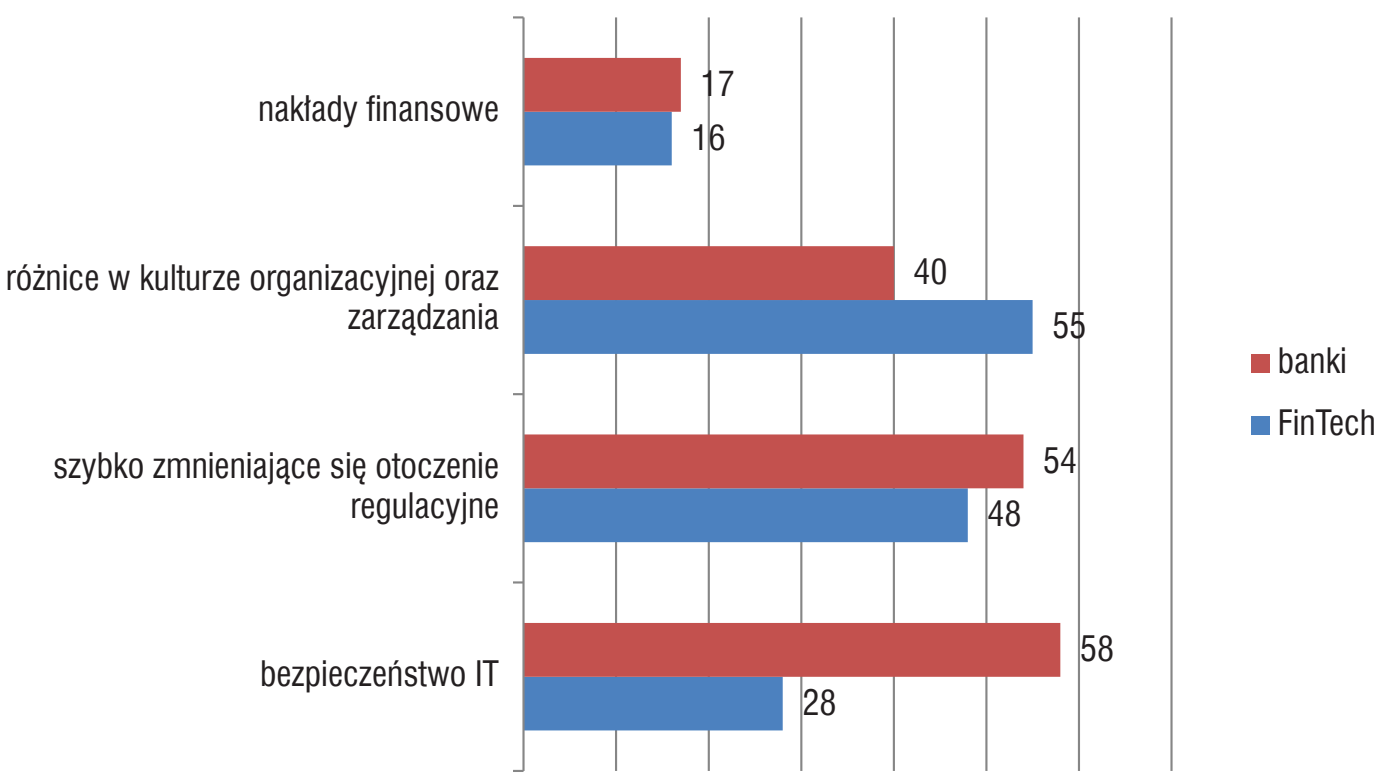

Źródło: Jak do rys. 2, s. 17.

13 Produkt white label jest produktem lub usługą wyprodukowaną przez sektor FinTech (producenta), którą banki przemianują i będzie to wyglądało tak, jakby same to opracowały.

14 Banki i fintech-y..., op.cit., s. 5. 


\section{Podsumowanie i wnioski końcowe}

Europejski rynek płatności stoi przed dużym wyzwaniem związanym z wdrożeniem unijnej dyrektywy PSD2. Ten akt prawny przyniesie korzyści nie tylko dla banków, lecz również dla innych firm z innych sektorów niż finansowy, które chcą wprowadzić nowe produkty i usługi na rynek. Polskie przedsiębiorstwa oraz sektor bankowy stoją przed dużą szansą, ponieważ rynek finansowy w Polsce jest nowoczesny oraz dynamicznie się rozwija. Dyrektywa PSD2 może umożliwić opisanym podmiotom ekspansję na rynki unijne, ponieważ zostaną ujednolicone standardy, co wpłynie na zniesienie barier między państwami członkowskimi Unii Europejskiej.

Implementacja dyrektywy PSD2 do prawa krajowego będzie z pewnością jedną z najważniejszych kwestii warunkujących rozwój sektora finansowego, ze szczególnym uwzględnieniem sektora bankowego. Obecnie trudno jest stwierdzić, czy implementacja tej unijnej dyrektywy przyniesie tylko korzyści dla banków. Dyrektywa PSD2 nie wpłynie na rozwój sektora FinTech, będzie jednak dla nich wsparciem w rozwoju. Na razie trudno jest prognozować, jak ukształtuje się rynek usług płatniczych i dopiero za około dwa lata będzie można stwierdzić, jaką rolę będą odgrywać poszczególni uczestnicy rynku.

W obecnych czasach klienci oczekują coraz nowszych rozwiązań płatniczych oraz usług. Sektor FinTech zaczął być postrzegany przez banki jako źródło najwyższej jakości innowacji. Programy inkubacyjne oraz akceleracyjne ${ }^{15}$ mają za zadanie przezwyciężyć bariery we współpracy FinTechów z bankami oraz zintegrować obszary, w których sektor bankowy potrzebuje najbardziej innowacyjnych produktów i usług, np.: podpis elektroniczny, automatyzacja w obszarze rozliczeniowym czy interfejs banków.

Podsumowując, narodowe implementacje dyrektywy o usługach płatniczych PSD2 znacząco wpłyną na rozwój sektora finansowego (nie tylko dla branży FinTech, ale również dla banków). Obecnie trudno jednoznacznie stwierdzić, czy będzie to miało pozytywny wpływ, jednak otwarcie sektora bankowego przyniesie dużo zmian i wiele możliwości dla konsumentów. Gospodarka oparta na API (API economy) ma szansę przynieść wiele korzyści poprzez nawiązanie współpracy sektora bankowego z firmami zewnętrznymi oferującymi rozwiązania API, których zakres jest znacznie szerszy, niż to zostało przewidziane w dyrektywie PSD2. Powyższe rozwiązania mają szanse

15 Dobrym przykładem programu akceleracyjnego jest Startup Collider założony przez PwC i prowadzony w Europie Środkowowschodniej; jest to tzw. laboratorium dla projektów opracowanych przez startupy. 
zrealizować się przy dobrej woli współpracy po obu stronach, co wpłynie na powstanie w przyszłości nowych modeli biznesowych.

\section{Banking sector and FinTech in the context of the PSD2 directive implementation}

The aim of the article is to define the prospects for the development of cooperation between the banking sector and FinTech in the context of the implementation of the PSD2 directive. First, attention was drawn to the changing role of banks that have already taken actions to use the opportunities related to the implementation of this EU regulation of the European payments market. It has been pointed out that the opening of the banking system will result in close cooperation with the FinTech sector, so-called API economics, and this will affect the emergence of new business models. Next, new solutions developed in the PSD2 Directive were presented, with reference to new regulatory technical standards between the banking sector and third parties. The last issue raised in the article concerns cooperation between banks and the FinTech sector. Financial institutions should use innovative solutions offered by fintechs and thanks to that they will increase operational efficiency and create products and services better suited to clients' needs. In the next years, it will be possible to observe how the financial services market will change and which entities will play a significant role in it.

Keywords: Payment Services Directive 2, open banking, FinTech sector, third-party payment service provider (TPP)

\section{Literatura}

1. Banki i fintech-y - małżeństwo z rozsądku, raport PwC, czerwiec 2017, https://www. pwc.pl/pl/pdf/fintech-2017-raport-pwc.pdf

2. Commission Delegated Regulation supplementing Directive 2015/2366 of the European Parliament and of the Council with regard to regulatory technical standards for strong customer authentication and common and secure open standards of communication, European Commission, Brussels 27.11.2017.

3. Duże banki w Europie Środkowej przygotowują się do wejścia w życie PSD2, małe czekają na rozwój wydarzeń, https://www².deloitte.com/pl/pl/pages/press-releases/articles/duze-banki-w-europie-srodkowej-przy-gotowuja-sie-do-PSD2.html 
4. Dyrektywa Parlamentu Europejskiego i Rady (UE) 2015/2366 z dnia 25 listopada 2015 r. w sprawie usług płatniczych w ramach rynku wewnętrznego zmieniająca dyrektywy 2002/65/WE, 2009/110/WE, 2013/36/UE i rozporządzenie (UE) nr 1093/2010 oraz uchylająca dyrektywę 2007/64/WE, DzU UE L.2007.319.1 ze zm.

5. Dyrektywa PSD2 zmienia rynek. To poczatek ekonomii API, https://www.itmagination.com/pl/booster/the-psd ${ }^{2}$-directive-is-changing-the-market/

6. Komisja Europejska opublikowała dzisiaj standardy techniczne (RTS) do dyrektywy PSD II, https://alebank.pl/komisja-europejska-opublikowala-dzisiaj-standardy-techniczne-rts-do-dyrektywy-psd-ii/?id=236100\&catid=18911

7. Redrawing the lines: FinTech's growing influence on Financial Services, Global FinTech Report 2017, https://www.pwc.com/jg/en/publications/pwc-global-fintech-report-17.3.17-final.pdf

8. Sprawozdanie $w$ sprawie FinTech: wpływ technologii na przyszłość sektora finansowego (2016/2243 (INI)), Komisja Gospodarcza i Monetarna, Parlament Europejski, 28 kwietnia $2017 \mathrm{r}$.

9. Szpringer W., Szpringer M., Nowe zjawiska w regulacji rynku usług płatniczych (wybrane problemy na tle projektu noweli do dyrektywy PSD), „E-mentor” nr 4(56), 2014.

10. World Retail Banking Report 2017, Capgemini, Efma, https://www.worldretail- bankingreport.com/

11. Wszystko o PSD2 (Payment Services Directive 2), https://www2.deloitte.com/pl/pl/ pages/doradztwo-prawne/topics/PSD2.html 